\title{
SODIUM REMOVAL AND CLEANING OF REUSABLE HARDWARE
}

L. E. Chulos

DECEMBER 1967

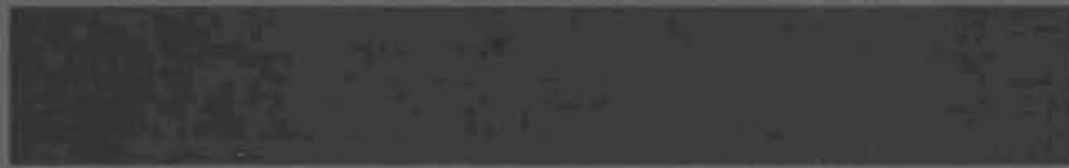

\section{AEC RESEARCH \& DEVELOPMENT REPORT}

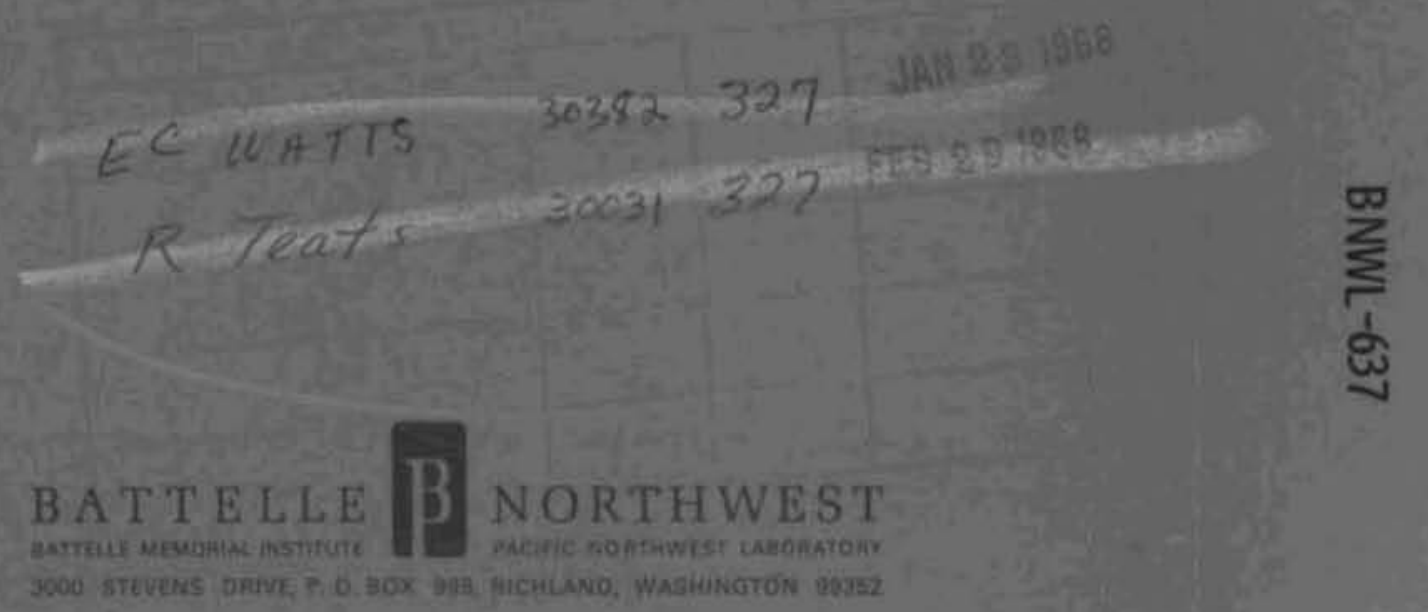




\title{
LEGAL NOTICE
}

This report was prepared as an account of Government sponsored work. Naither the United Stoles, nor the Commistion, nor any person acting on behalf of the Commission:

A. Makes any watranty or representation; expressed or implied, with respect to the accuracy, completeness, or usefulness of the information contained in this report, or that the une of any information, opparatus, method, or process dicklosed in this report may nat infringe privately owned rightss or

B. Assumes any, liabilities with respect to the use of, or for damages resulfing from the use of any information, opparotus, method, ar process disclosed in this report.

As used in the obove, "person octing on behalf of the Commisvion" Includes any employee or contractor of the Commission, or employee of such controctor, to the extent that such employee or contractor of the Commission, of employee of such contractor prepares, disteminotes, or provides access to. any Information pursuont to his employment of contract with the Commission, or his employment with wuch contractor.

\author{
PACIFIC NORTHWEST LABORATORY \\ RICHLAND, WASHINGTON \\ operaled by \\ BATTELE MEMORIAL INSTIUTE
}

for the

UNITED STATES ATOMIC ENERGY COMMISSION UNDER CONTRACT AT(45-1)-1830 
UC-25 Metals, Ceramics and Materials

Sodium Removal and Cleaning

of Reusable Hardware

by

\author{
Leo E. Chulos \\ Senior Technician \\ Nuclear Metallurgy Unit \\ Metallurgy Research Section \\ Metallurgy Department
}

recember 1067 


\author{
SODIUM RFMOVAL AIID CLEANING \\ OF REUSABLE HARDWARE \\ L。 E。 Chulos \\ Metallurgy Research Section \\ Metallurgy Department
}

GENERAL

There are a number of ways in which sodium contaminated articles may be cleaned for reuse. The method utilized is dependent on a number of factors; namely, the size of the article, degree of cleanliness required, and geometrical configuration, to name a few, Large articles such as pipes and large valves can be effectively cleaned by totally immersing them in a hot oil bath. The parts are usually placed in a wire mesh basket and lowered into the hot oilo The basket is agitated every hour or so and the liquid sodium flows out of the pipes or valves and sinks to the bottom of the tank. The oil covering prevents sodium reactions with the atmosphere. After visual inspection indicates that the sodium has been removed, the parts can then be taken from the hot oil and cleaned further with saturated steam. This method is recommended for cleaning radioactively contaminated parts, since the oil can be aisposed into barrels and treated as contaminated liquid waste.

Large pipes that are not filled with solid sodium, but only have residual traces, may be effectively cleaned by placing them in a vice attached to a heavy metal table in an approved open area and applying saturated stean to them at about fifty pounds pressure. This should be followed with a liquid water rinse 。 
Small tubes, valves, specimens, etc, may be cleaned in an inert atmosphere box using a mixture of steam and nitrogen applied under low pressure through a nozzle. There is no assurance, however, that all of the sodium in relatively inaccessible areas has reacted. Also an inert atmosphere box and associated. piping are costly. Another disturbing possibility is the chance of losing the inert atmosphere and creating a secondary reaction, such as a hydrogen explosion。

\section{DOWANOL-EB NEUTRALIZATION OF SODIUM}

A practice which has recelved some attention is the use of commercial solvents with an alcohol base to react with the sodium and remove it from contaminated parts. Frequently, the reaction rate is not controllable within acceptable limits, and a scum is left which is difficult to remove. Since data for this method of cleaning is generaily unavailable, extensive tests were conducted by the staff of Nuclear Metallurgy in the 321-A Creep Facility, and it was found that a commercial solvent (Dowanol-EB), manufactured by the Dow Chemical Company, gives extremely good results. The reaction of the Dowanol-EB and the sodium is slow, but predictable, and there is no scum left on the part being cleaned. The end product of the reaction is the spent Dowanol-EB and a soft residue which is easily removed by rinsing with water. Sodium reaction goes to completion, even in hard-to-get-at places such as screw threads, fittings, and inside valves.

The tests were conducted in a large, high bay area with adequate ventilation. The hydrogen which was generated bubbied up through the Dowanol-EB at the rate of five or six bubbles per second. This slow rate allowed no chance of a hydrogen accumulation and subsequent explosion. The reaction interface between the metallic sodium and the Dowanol-FB advances smoothily at a rate of approximately 
one twenty-fourth inch per $\mathrm{hr}$ in fresh Dowanol-EB. When Dowanol-EB which had been standing in an open beaker for one week was used, the moisture absorbed from the atmosphere speeded the reaction rate to about $1 \mathrm{in} / \mathrm{hr}$; however, the reaction was under complete control and the temperature rise of the containment beaker was small.

The procedure for cleaning a sodium contaminated article begins by placins the part in metal container and just covering the part with Dowanol-EB. The cleaning operation should be conducted in a ventilated hood or well ventilated room. After $24 \mathrm{hrs}$, the reaction is usually found to be complete and a white residue is left in the bottom of the container. To insure complete reaction, add about $10 \mathrm{ml}$ of water to the fluid. If any bubbles are observed, wait until they cease and then add an additional. $10 \mathrm{ml}$ of water. Continue this procedure until the resultant mixture is 50 percent water or all bubbling has ceased. At this point, remove the part and totally immerse it in water to remove all traces of the residue, whe part can then receive a final cleaning rinse in absoiute ethyl alcohol. The spent Dowanol-FB and reaction residue can be safely flushed down a sink, since the Dowanol-FB is completely miscible in water. The tap should be running during flushing to insure good dilution.

Another method of Dowanol-EB cleaning was successfully used to remove sodium from the surface of test elements contained in a large capsule illustrated in Figure I. Dowanol-EB was introduced into the capsule through the bottom and allowed to flow up and around the test rod and specimens until it reached a point fust above the uppermost part of the test rod. The level was observed at the transparent Tygon transfer tube. Helium was then introduced into the bottom of the capsule at a slow purge rate and ellowed to bubble up and around the specimens. This counterflow action assisted the Dowanol-EB in getting at all areas of the specimens, decreasing reaction time 
and insuring complete sodium removal. The helium also served an additional function of sweeping out toxic gasses and hydrogen which had been generated. The gasses exited through a valve at the top of the capsule to a gas washing bottle containing kerosine for a bubbler, thus preventing back flow of the gas. Three gallons of Dowanol-FB was used in the reaction process and two gallons were used for flushing the residue. Peaction was completed in about $24 \mathrm{hrs}$, as noted by the absence of bubbling in the bubbler when the helium purge was secured.

\section{PRECAUTIONS}

Downol-EB has a flash point of $165^{\circ} \mathrm{F}$, and requires proper safety measures for handing and storing. It is also moderately poisonous on inhalation, and is readily absorbed through the skin. In both instances, the material is capable of producing degradation of the blood when the threshhold value of $50 \mathrm{ppm}$ is exceeded. Consequently, good ventilation and skin protection are necessary。

\section{RESUITS}

Figures 2 through 4 illustrate the cleaning effectiveness of the Dowanol-EB method. Figure 2 shows two, $1 / 2-$ in ID, 6-in Iong capsules which were filled to within one inch of the top with sodium and welded closed. Two, 1/16-inch holes were drilied as shown, and the capsules were then totally immersed in nnwanol-EB for cleaning by the previously described method. Upon completion of the reaction, they were cut open. The very small amount of residue remaining inside the capsule was easily filushed out with water。

Figure 3 illustrates a I/2-inch ID, 2-in long tube, which was completely plugged with sodium. The ferrule was also covered with sodium oxide. After 24 hrs immersion in Dowenol-EB without water addition, the tube exhibited no traces of sodium or sodium oxide. Oxide was even removed from under the ferrule which turned easily on the tube after cleaning. 
FIgure 4 is a photomicrograph of the surface of a 304 ss plate which was polished to a yellow diamond finish and then subjected to molton sodium. After sodium exposure, the plate was immersed in a beaker of Dowanol-FB, and allowed. to react totally. The photomicrograph shows no evidence of attack of the previously polished surface.

\section{CONCIUSTONS}

1. Dowanol-FB provides a safe and flexible method for cleaning reusable parts contaminated with sodium or sodium oxide.

2. Experimental tests reveal that the reaction rate of sodium with Dowanol-EB can be repulated by water additions and that the end products, Ilquid and residue, can be readily dissolved and flushed with water. 
1. TID-5277, IIquid Metals Handbook, Sodium-NaK Supplement, July 1, I955, AEC, Department of the Navy, Washington D. C.

2. MAA-SR-4383, A Study of Sodium Fires, Atomics International.

3. Handling Sodium, Industrial Chemicals Division, Ethyl Corporation。

4. Sodium Reactor Experiment Operations Manual, Atomics International. 


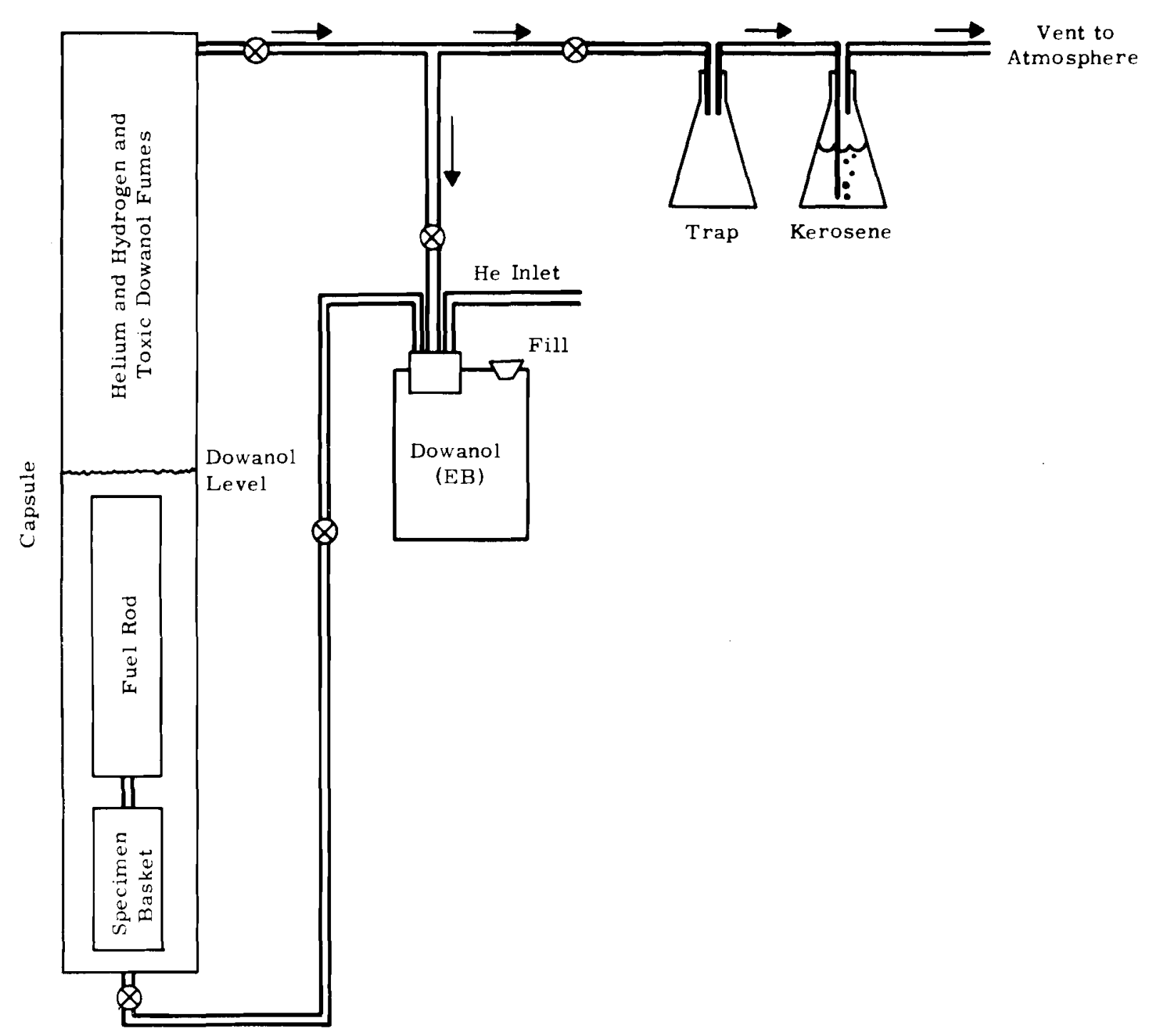

FIGURE 1

Schematic for Removing Residual Sodium from Fuel Rod and Specimens with Dowanol (EB) 


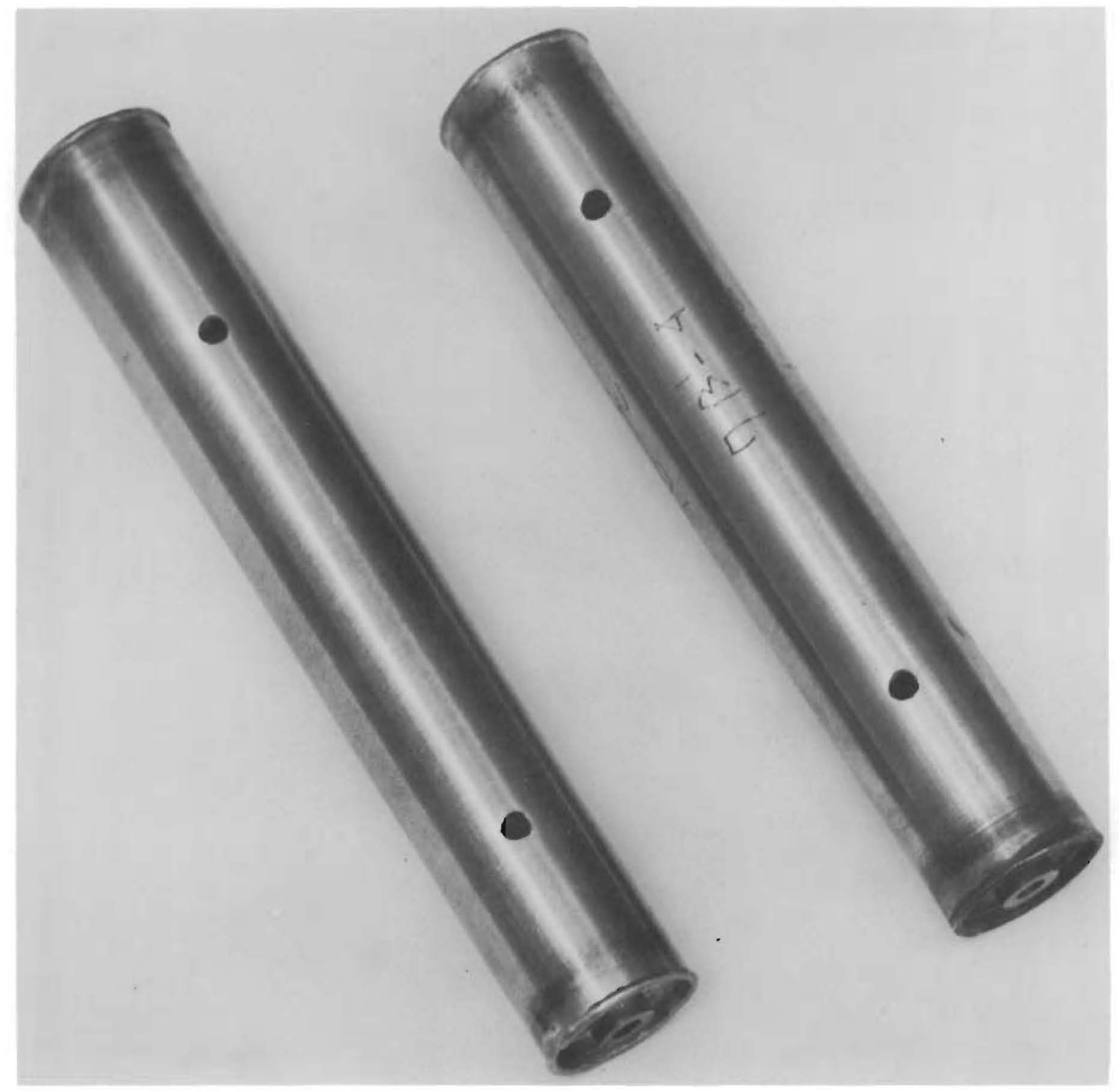

FIGURE 2: Sodium Filled Capsules Which were Cleaned by Using Dowanol ( $E B$ )

AXC.RL RICHLAND, WASH. 


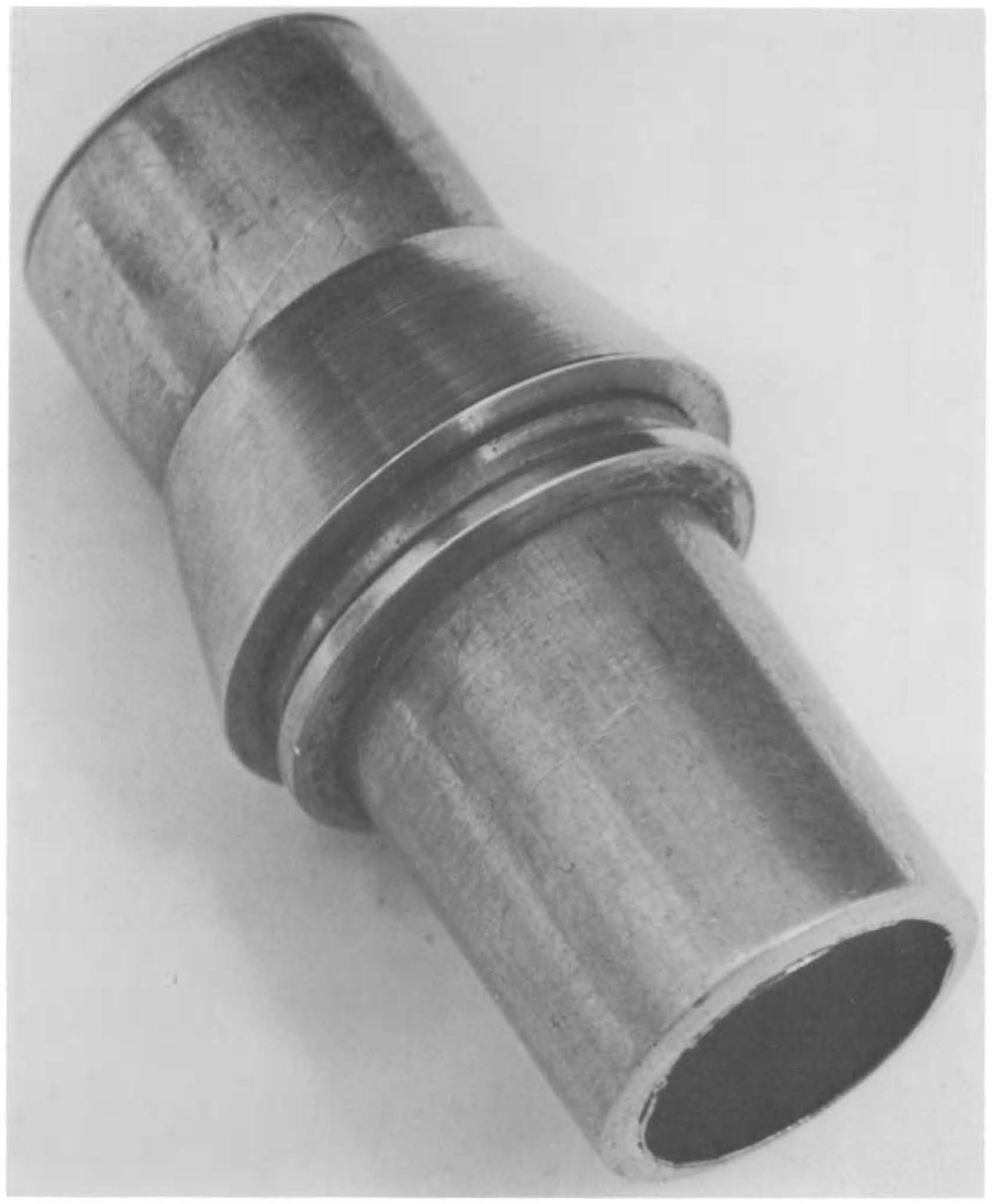

FIGURE 3: Sodium Filled Tuie and Heavily Sodium Oxide Covered Ferrule After Cleaning by Using Dowanol (EB) 


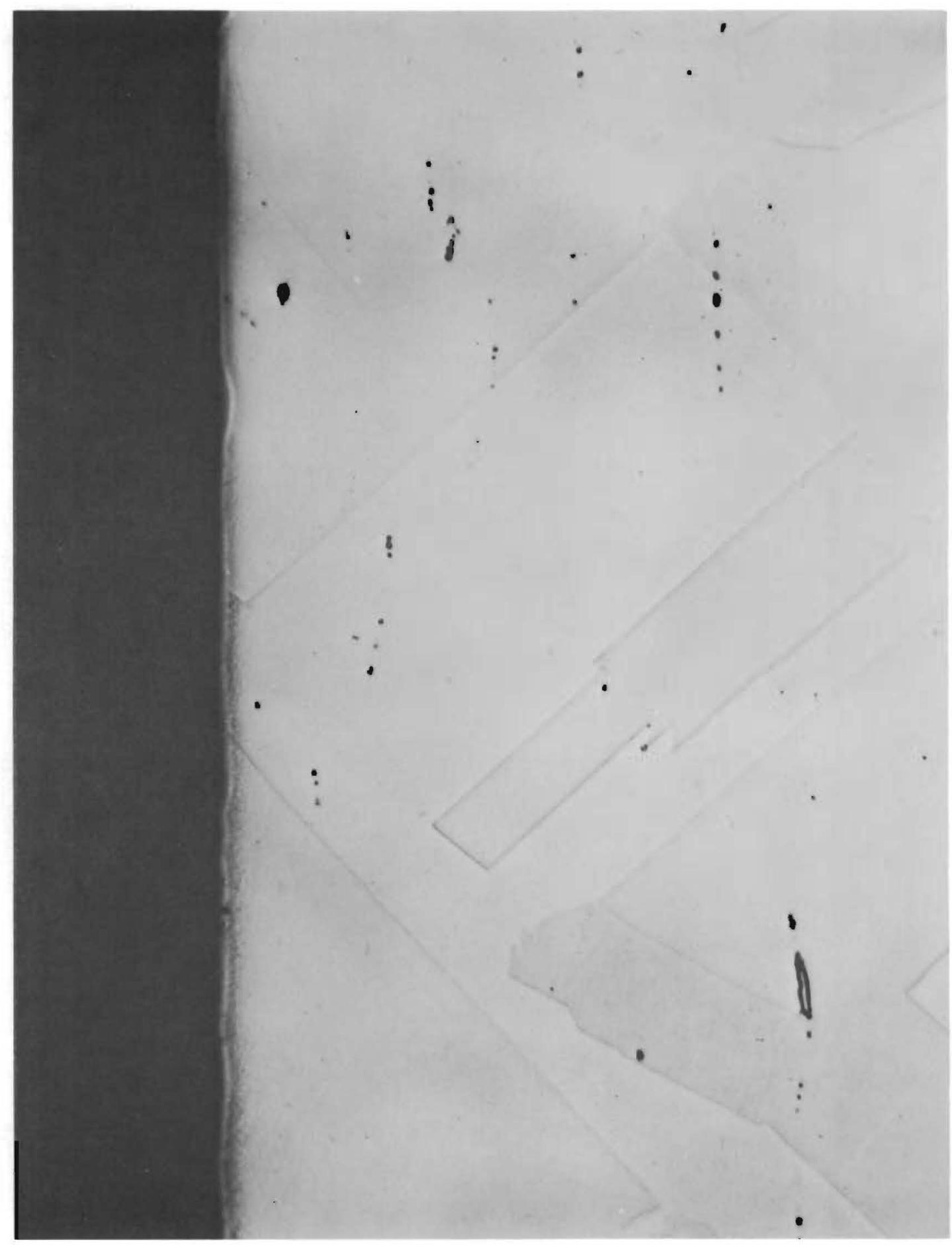

FIGURE 4: Polished Stainless Steel Plate Showing No Attack by Dowanol (EB) Cleaning Process 
No. of

Copies

1

2

2

4

1

3

1
Argonne National Laboratory LMFBR Program Office 9700 South Cass Avenue Argonne, Illinois, 60439

AEC Chicago Patent Group

Go $H$ o Lee

$R_{0} K_{\text {。 Sharp }}$

AEC Richland Operations Office

Co Lo Robinson

Technical Information Library

AEC Senior RDT Site Repo, Richland

$P_{0} G_{0}$ Holsted (2)

Lo Ro Lucas

Jo Ho Sako

$\mathrm{AEC}_{2}$ Washington, $\mathrm{D}_{0} \mathrm{C}_{0}$

$J_{0} J_{0}$ Morabito

Battelle Memorial Institute 505 King Avenue

Columbus, Ohio, 43201

Division of Technical Information Extension

University of California

Lawrence Radiation Laboratory

Livermore, California

James Wo Hadley 
Battelle-Northwest

F。 Wo Albaugh

$E_{0} R_{0}$ Astley

A。 $t$ o Bement

$T_{0} K_{0}$ Bierlein

Go R。 Bloom

$R_{0} V_{0}$ Bowersock

$J_{0} J_{0}$ Cadwell

I。 Eo Chulos (30)

To To Clauds on

L。 J。 Defferding

R。 Io Dillon

Do Ro Doman

R. V。 Dulin

$R$ o $W_{0}$ Hardie

$R$ o Jo Hennig

R。 Io Knecht

Do Co Lehfeldt

$M_{0} K_{0}$ Millhollen

Jo Eo Minor

$R_{0} S_{0}$ Paul

Lo To Pederson

Wo Do Roake

R。 H。 Scott

$D_{0} W_{0}$ Shannon

F。 Ro Shober

Jo Bo Vetrano

Technical Information Files (5) 